\title{
"ENTREPRENEURS ARE SUPERHEROES OF SOCIETIES": INSIGHTS ON HOW LAUNCHING AND OPERATING A PRESCHOOL DURING THE COVID-19 PANDEMIC SNATCHED ALL MY SUPERPOWERS
}

\author{
Dr Marcia Lebamboํㅜ Orcid ID: https://orcid.org/0000-0002-2944-6802
}

\begin{abstract}
:
The founding father of entrepreneurship, Schumpeter, described entrepreneurs as true heroes of society, primarily due to their contribution to value creation and their ability to create something new, thereby driving economic evolution. Perhaps as a new business owner, I resonated with the definition prior to the advent of the COVID-19 pandemic. I ventured into my business full of vigour and ready to become a superhero of my community. Almost a year after the outbreak of the coronavirus, my superhero wings have withered. In this article I share my experience in launching a new business in 2020 - the year of the start of the COVID-19 pandemic. My micro-level business start-up is a preschool located in Soshanguve, one of South Africa's townships in the City of Tshwane.
\end{abstract}

\section{Introduction}

Entrepreneurship scholars and researchers postulate that 70 percent of small to micro and medium enterprises (SMMEs) in South Africa collapse within the first three to five years of inception (Bushe, 2019; Leboea, 2017; Worku, 2016; Lebambo \& Shambare, 2017). There are various reasons for business failure: businesses that are not financially viable, difficulty in securing loans, the lack of training opportunities and mentorship, and a shortage of entrepreneurial skills. This is the case for many start-ups that launch their business ventures under stable economic conditions. However, my experience of launching and operating a business during a global pandemic, attested that it takes digging deeper than tangible resources to succeed as an entrepreneur.

I graduated with a PhD in Business Management from the Tshwane University of Technology Business School, majoring in entrepreneurship. In addition to the formal education, I have attended a number of skills development training in entrepreneurship. Furthermore, I have conducted feasibility and viability studies to assess the practicality of the preschool business idea. This was followed by a consultation with several mentors and advisors, of which many own successful businesses. As part of the important pre-business checklist, I apparently ticked every box. I was ready to embark on my entrepreneurial journey.

In December 2019, I use some of my savings, refurbished my house and turned it into a preschool. Dr Marcia Lebambo Academy started operating in January 2020. The feeling of seeing an idea turn into a living business can be best described using Schumpeter's words: "a true hero of society". It felt as if I just surmounted Mount Everest. Finally, after months of devoting time, effort and assuming the financial, physical and social risks, the hard work finally paid off when three weeks after launching the academy, more and more kids enrolled at our school.

${ }^{1}$ University of Johannesburg, School of Tourism and Hospitality

E-mailmlebambo@uj.ac.za 
It was at this moment that I felt Schumpeter's definition of entrepreneurs as superheroes resonate with me. I was the superhero in my community. I managed to establish a preschool and employed three full- time teachers, one part-time replacement teacher and a full-time cook. In total, five people were employed in my preschool. A month later, the spread of COVID-19 reached South African shores, and subsequently the country went into lockdown for a period of eight months - shutting down business operations and halting economic activities. When we were finally given the greenlight by the South Africa government, only $5 \%$ of our kids returned to finish the academic calendar with us. I was devastated and I lost all my superpowers.

\section{Challenges of operating the preschool during the lockdown}

As stated previously, many small businesses collapse in their first three to five years of operating when economic conditions are normal. However, launching and operating a business during a pandemic is a different scenario. One operates the business under a great deal of uncertainties and fears. The most daunting decision was to decide whether to continue or shutdown the business for good. In navigating this predicament, we asked ourselves the following questions:

1. Is it viable to continue operating with only a handful of kids? If the answer is yes:

2. Would we be able to protect the lives of the kids and adhere to COVID-19 regulations?

3. What kind of support is necessary to enable the preschool to continue during and post-COVID?

\section{Is it viable to continue operating with only a handful of kids?}

The most daunting decision to make was deciding if it was viable to continue operating if only a handful of kids returned to school. In an attempt to answer this question, we conducted a viability study to determine realistically how many kids could be expected to return to finish the academic year (September to December, 2020), based on the expected market size. Given the 5\% that returned to school and the interest shown towards our online learning recovery plan, we decided it was viable to open the doors for learning again.

\section{How are we going to protect the lives of the kids and adhere to COVID-19 regulations?}

In responding to the question of the safety of learners, we first sought out to understand the guidelines pertaining to safekeeping Early Childhood Development (ECD) centres during the pandemic. In addition, we used the World Health Organisation COVID-19 safety measures, as well as the South African Government Covid-19 safety guidelines to direct our steps. We immediately implemented the following measures:

1. Handwashing policy: Everyone working in our preschool was made aware that handwashing is one of the most important ways of preventing COVID-19, and therefore it is compulsory to wash hands frequently with soap and hand sanitizers. This applies to all staff, volunteers, and children. This is done when they arrive, during sessions, and when they leave the premises. Some of the activities that will require washing of hands prior and after executing them, include feeding a child, changing a nappy, and after visiting the toilet or helping a child with toileting.

2. Keep a distance of 1.5 meter: In the ECD centre, children were placed 1.5 meter from one another. Although this was difficult, since children are used to companionship and enjoy playing with their peers, the kids were reminded that no hugs were allowed at school. They were often encouraged to touch elbows if they wanted to greet a friend. These measures were implemented to assist in maintaining social distancing which reduces the spread of the virus.

3. Wearing gloves: The glove policy was enforced as another measure to prevent the spread of COVID-19.

4. Wearing masks: The wearing of masks was made compulsory. This was important to help prevent the spread of the virus from one person to another. The kids were reminded that masks should not be shared, to wash cloth masks with warm water and soap frequently, and not to re-use disposable masks.

5. Policy on the non-sharing of personal items: Staff and children were reminded not to share personal items like face masks, towels, facecloths, toothbrushes or linen. Each person must have their own personal items which should be clearly marked and regularly cleaned.

6. Cleaning routine for the ECD centre: We undertook deep-cleaning at our facilities prior to re-opening the schools as well as frequently during operation. This included toys, chairs, tables, and sleeping rooms. The ECD centre was always maintained in a clean and hygienic condition, because thorough cleaning of surfaces is one of the most important ways of reducing the number of germs and the spread of COVID-19. 


\section{What kind of support is necessary to enable the preschool to continue during and post- COVID-19?}

Research into entrepreneurial ecosystems is in tandem with the notion that business ventures emerge and grow where there is a strong entrepreneurial ecosystem that offers a conducive business environment for the businesses to succeed. According to Mason and Brown (2014), an entrepreneurial ecosystem is a combination of various social, political, economic, cultural, technology, market and network elements within a region, and that support the development and growth of innovative start-ups, that assist and inspire nascent entrepreneurs to take on the risks of starting and funding high-risk ventures. In South Africa, all businesses were depending on the Presidential COVID-19 task team for marching orders. Regularly, the task team led by the President of South Africa, Mr. Cyril Ramaphosa, updated citizens daily on the next move regarding the pandemic. These regular and informative updates played a key role to keep us updated to be able to plan around the lockdown. In addition, the President immediately outlined various economic relief programmes and aid for small businesses. These ranged from relief grants in the form of cash, to negotiating with banks for payment plans on business loans. The biggest support the preschool needed was the cash relief fund to help pay for the teacher salaries and the utility bills after they were out of business for eight months. Of the many relief grants announced by the government, we applied for two relief fund programmes: (1) the Social Development Early Childhood Development Grant and (2) the National Youth Development Agency Youth Enterprise Relief for COVID-19. At the time of submitting this article, we were still busy with the application process for the former. For the latter, we have received a once-off relief grant that assisted in paying for the mortgage and the employees in 2020.

The fundamental idea of an entrepreneurial ecosystem is to create an environment conducive to supporting innovation, forming new successful ventures, and generating the corresponding sustainable employment growth within a specific geographic region (Brekker, 2015; Garud, Kumaraswamy, \& Karnoe, 2010). Given my experience operating a start-up business venture during COVID-19, I can confirm that the attempt of the South African Government to resuscitate the country's ailing economy by supporting small businesses, were somewhat encouraging. What remains unclear is whether these interventions are enough, and in addition, if the imminent collapse of SMEs can be contained with the economic relief programmes.

\section{Conclusion and recommendations}

Riani (2020) asserts that there is no single challenge that can stop passionate entrepreneurs from successfully launching a start-up. The latter author asserts that contrary to popular belief, the statement is not motivational, but it is a fact. Since successfully launching and operating the pre-school during a pandemic, I can confidently say that I concur with the latter author's contentious statement. In my opinion, as a leader and with a high-ranking position in a school, I am responsible for the overall operation and functioning of the school. Alternatively, the statement does not seek to undermine the complexity of COVID-19 and its calamitous impact on many small businesses, and the role the government plays in assisting small businesses to get back on their feet. However, ultimately, resilience in the face of what was potentially a damaging disruption to schooling in recent times, kept our preschool operating to date.

\section{Recommendations for the school to survive during this pandemic}

For a school to function and achieve excellence, a number of factors were considered. These include:

1. Implementing a flexible curriculum: The use of Zoom and WhatsApp messaging to facilitate some of our classes and communication to the learners, assisted a lot during this challenging period. Flexible curriculum requires commitment and creative teaching methodologies from the teachers and support from the preschool management. The preschool needs to ensure that its curriculum is adaptable and accessible to learners' needs and capabilities. A simple voice note and group video call on WhatsApp kept us closer to our kids. The random acts of compassion and flexible teaching approaches made the difference.

2. External client relation: Facilitating school interaction with parents, the school governing body and other stakeholders.

3. Cleanliness, safety and security: Ensuring that the school is a safe, hygienic learning environment for children.

4. Leadership, decision-making and conflict resolution: This is another important function of the school principal. As a leader, he or she should guide any conflict among learners, teachers, and school governing bodies and find better solutions. The management style and management skills of an ECD school principal/manager largely determined the success of the Centre. The style of management should create an atmosphere in which, staff, 
parents and children are happy and feel safe, especially during these unprecedented times of Covid- 19 .

5. Lead with love: The world is still reeling from being ambushed by a pandemic of the Covid-19 magnitude. This will naturally spur on a lot of confusion, panic and fear, because it is something most of us have never dealt with before. This requires leaders to lead with love. This period requires empathetic and authentic leadership that will inspire a positive mindset among learners, parents and teachers during these difficult times.

\section{References}

Brekke, T. (2015). Entrepreneurship and path dependency in regional development. Entrepreneurship \& Regional Development, 27(3-4): 202-218.

Bushe, B. (2019). The causes and impact of business failure among small to micro and medium enterprises in South Africa. Africa's Public Service Delivery and Performance Review, 7(1): 2310-2152.

Garud, R., Kumaraswamy, A., \& Karnoe, P. (2010). Path dependence and path creation. Journal of Management Studies, 47(4), 760-774.

Lebambo, MM., \& Shambare, R. (2017). Entrepreneurship policies versus practice: A great divide for tourism establishments in rural South Africa. Global Business and Technology Association 1(1): 330-335.

Leboea, S. T. (2017). The factors influencing SME failure in South Africa. Masters dissertation. Cape Town: University of Cape Town.

Mason, C., \& Brown, R. (2014). Entrepreneurial ecosystems and growth oriented entrepreneurship. Paris: Final Report to OECD. Retrieved online at http://lib.davender.com/wp-content/uploads/2015/03/Entrepreneurial-ecosystemsOECD.pdf. [Accessed: 21 May 2021]

Riani, A. (2020). 5 Big Challenges to Launching a Startup and How to Overcome Them. Retrieved online at: https:// www.forbes.com/sites/abdoriani/2020/01/30/5-big-challenges-to-launching-a-startup-and-how-to-overcomethem/?sh=a34f1 cd33645 [Accessed: 10 January 2021].

Worku, Z. (2016). Barriers to the growth of small, micro and medium-sized business enterprises in the Vaal Triangle region of South Africa, African Journal of Science, Technology, Innovation and Development, 8(2):134-141. 